\title{
Prediction of Climate Risk Management in Infrastructure Projects
}

\author{
Senthil. J, M.Muthukannan, S H Robin Sham
}

\begin{abstract}
Risk Management in Construction Project is playing important role to achieve successes of the Project. Risk is in everywhere and every project particularly in construction has innumerable risks occurring before construction and during construction period. Most of the risks are repeatedly occurring but the impact \& probability of risk is varying. However, the climate risk may lead to impact the Time, Cost and losing an opportunity Cost of the project. This study is to create a model for risk data collection, risk analysis, risk interpretation with the combination of project schedule and cost, India climate is varying from states to states especially the annual number of raining days different from 10 to 130 days throughout India and its impact the construction schedule $3 \%$ to $36 \%$ on average, Temperature is verifying for winter (0C to 25C) and summer (25C to 50C) is also impact the productivity of project this will reflected in the Project Cost 1\% to 10\% on average. The History of Climate we can identify the Climate Risk, Environment Risk, impact the time and Cost. However, this paper is measuring and handling risks to help for upcoming construction projects.
\end{abstract}

Keywords: Risk Management, Climate, Time, Cost.

\section{INTRODUCTION}

Predication of Risk Management is key to the Successes Projects can deliver in on time and within the Budget Cost. Risk is accruing everywhere and anywhere but the impact opportunity to negative risk will impact the Project. In this paper we discussed about how to Predict the Climate Risk Management. Throughout India we have multiplicity of climates and different types of seasons - winter, monsoon, post-monsoon and summer, each Seasons affect the Project duration and Indirect cost of project, Mainly the rain fall seasons affecting Project by annually 10 to 130 days and its impact the construction schedule and Cost. Winter Season the temperature is verifying for winter (0C to $25 \mathrm{C}$ ) and summer $(25 \mathrm{C}$ to $50 \mathrm{C}$ ) In some states, Cyclone affect in the Coastal Zone is High, This paper we analyse the risk impact based historical climate date and applied the Historical simulation statistical model to predict the climate risk management in infrastructure projects

\section{DATA COLLECTION}

Primary risk data collected from Climate impact on constructed in the period from 2000 to 2018. Collection of data was performed by the method of survey and

Revised Manuscript Received on September 10, 2019.

Senthil. J, Research Scholar, Department of Civil Engineering, Kalasalingam University, Srivilliputhur, Tamil Nadu, India.

Dr.M.Muthukannan, D.C.E.(Hons),BE,M.E.,Ph.D (Transportation), Professor / Former Head, Department of Civil Engineering, Kalasalingam University, , Srivilliputhur, Tamil Nadu, India.

Dr.S H Robin Sham CBE, BSc, PhD, DIC, FCGI, FRSA, CEng, FICE, FIStructE, FHKIE, Sector Managing Director, Transportation, Pan-Asia, Team Leader MTHL Project, AECOM will be different form Project to Project Positive risk give

interviewing of engineers-in-charge in construction companies. The data were collected for zone wise North area, South area, North East area, and West area its further divide in to divided in three groups:

1. New infra construction (This new proposed and Construction projects of Bridge, bypass Road, Metro rail)

2. Upgradation infra Construction (2 lane to 4 lane road upgradation)

3. Renovation infra projects

Table 1: New infra Construction climate impact details

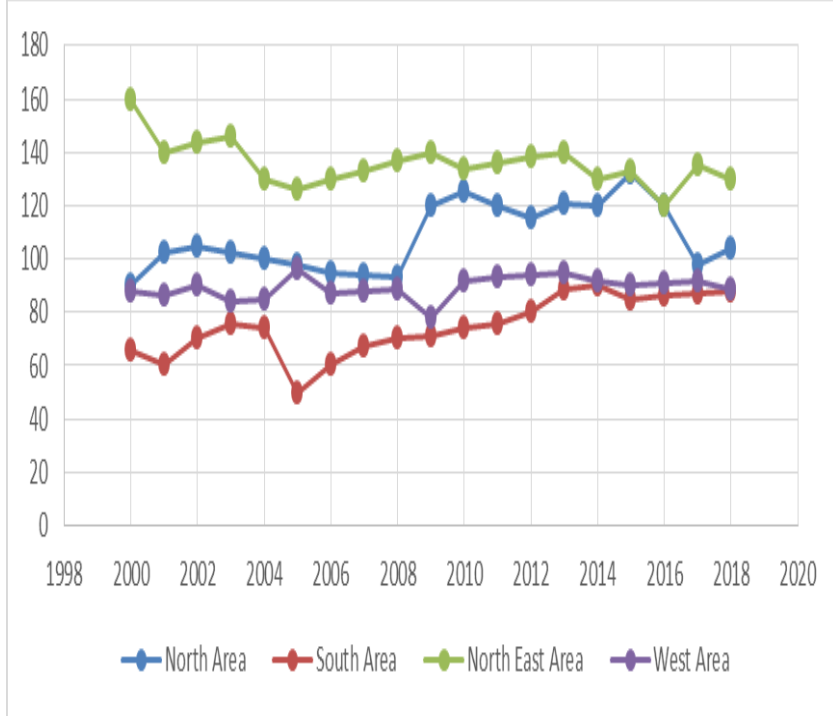

Table 2: Upgradation of infra construction details

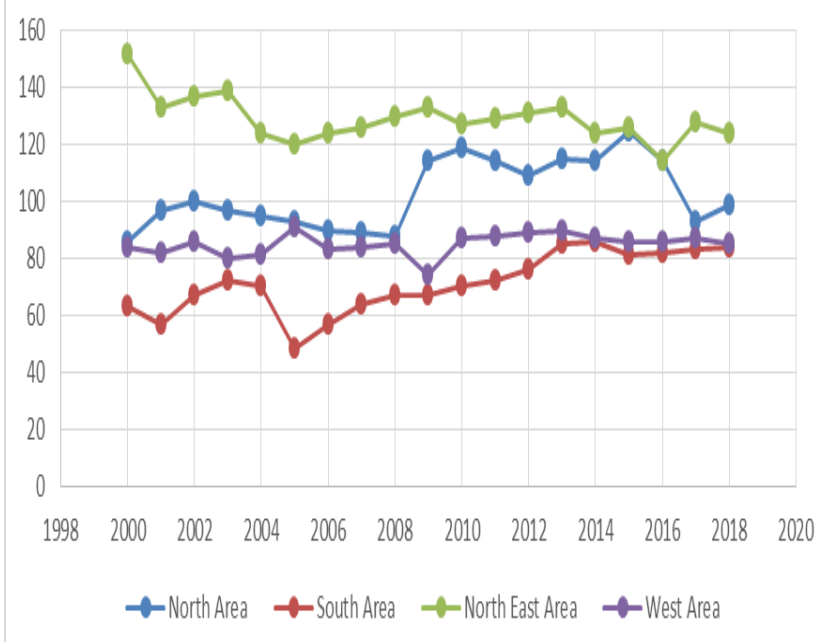

Published By: 
Table 3: Infrastructure renovation projects details

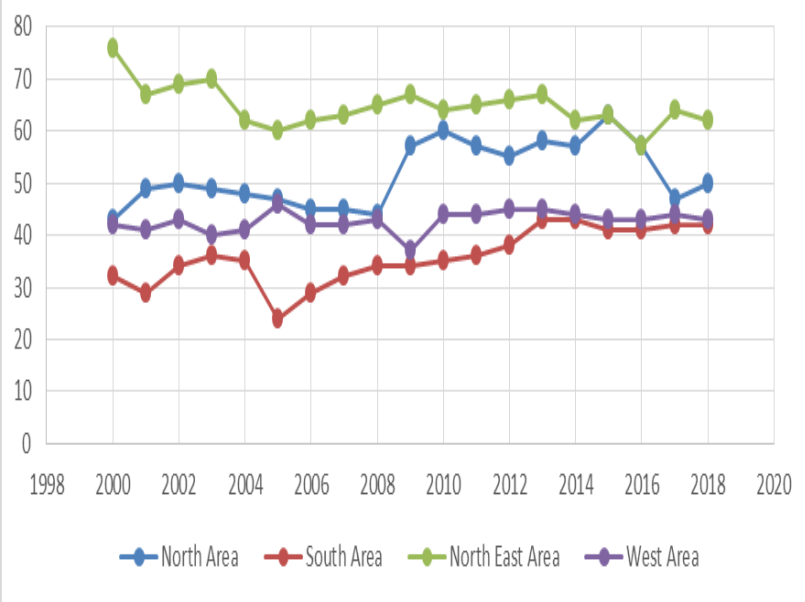

\section{RISK IN INFRA PROJECTS}

Generally, infra construction risks were split into many ways, such as Indoor and outdoor risks. Climate condition, politics, natural calamities, and accidents are coming into the outdoor risk category. Local materials availability, labour productivity, efficiency of sub-contractor, relevant resources, and site conditions are all coming into the indoor risk. Many of the research experts are suggested some more risk factors in indoor and outdoor category, which is not included in the above list, based on their research survey and literature review. The aim of the work is to identify the most influencing risk factors for the projects

\section{HISTORICAL SIMULATION}

Risk-factors values were observed for the historical simulation approach. Zm-n .......Zm. The changing observed risk factors are denoted by $\mathrm{Xm}-\mathrm{n}+1 \ldots \ldots . \mathrm{Xm}$. The corresponding observation losses were computed with the help of loss operator. $1 \mathrm{k}=1[\mathrm{~m}](\mathrm{xm}-\mathrm{k}+1), \mathrm{k}=1, \ldots, \mathrm{n}$,

Where $1 \mathrm{k}-$ Loss (observed risk factor changes by the next time Xm-k+1)

Empirical VaR and ES were computed using loss distribution function at the different time limits are iid.

$$
\begin{aligned}
\widehat{\operatorname{VaR}}_{\alpha}(L) & =\widehat{q}_{\alpha}\left(F_{L^{n}}\right)=l_{[n(1-\alpha)]+1, n} \\
\widehat{\operatorname{ES}}_{\alpha}(L) & =\frac{\sum_{i=1}^{[n(1-\alpha)]+1} l_{i, n}}{[n(1-\alpha)]+1}
\end{aligned}
$$

where

$$
11, \mathrm{n} \geq \ldots \ldots \ldots \geq \ln , \mathrm{n} \text { is the ordered sample. }
$$

Simultaneously, For 10 days, loss of historical values was observed in the name of value-at-risk and this aggregated data were formulated as given below.

$$
l_{k}^{(10)}=l_{[m]}\left(\sum_{j=1}^{10} \mathbf{x}_{m-n+10(k-1)+j}\right), \quad k=1, \ldots,[n / 10],
$$

to compute the empirical $\mathrm{VaR}$ and ES. This approach is simple for execution and the components of dependence structure keeps in the form of risk-factor changes Xm-k. This approach is easy to implement and keeps the dependence structure between the components of the vectors of risk-factor changes $\mathrm{Xm}-\mathrm{k}$.

\section{CLIMATE RISK FACTORS}

The Climate risk factors were formulated by industrial experts and researchers. They were enumerated the risk from various projects such as highway, bridges, Railway projects, infrastructure projects etc. Environmental and geological risk factors are identified in zone-wise and formulated in table below. By this table, climate risk factors are influenced much in the duration of completion projects.

Table 4: Details of climate risk factor in Zone-wise

\begin{tabular}{|l|l|l|l|l|}
\hline $\begin{array}{l}\text { Climate Risk } \\
\text { Factors }\end{array}$ & $\begin{array}{l}\text { North } \\
\text { Area }\end{array}$ & $\begin{array}{l}\text { South } \\
\text { rea }\end{array}$ & $\begin{array}{l}\text { North } \\
\text { East } \\
\text { Area }\end{array}$ & $\begin{array}{l}\text { West } \\
\text { Area }\end{array}$ \\
\hline $\begin{array}{l}\text { Monsoon Rain } \\
\text { Impacted days }\end{array}$ & $\begin{array}{l}30 \text { to } \\
45\end{array}$ & 60 & $\begin{array}{l}130 \text { to } \\
90\end{array}$ & $\begin{array}{l}90 \text { to } \\
60\end{array}$ \\
\hline Weather Impact & 30 to & 30 & $\begin{array}{l}45 \text { to } \\
60\end{array}$ & 10 \\
\hline $\begin{array}{l}\text { Total Impact } \\
\text { days }\end{array}$ & 105 & 75 & 150 & 90 \\
\hline $\begin{array}{l}\text { Climate Risk } \\
\text { factor }\end{array}$ & $\mathbf{2 8 \%}$ & $\mathbf{2 0 \%}$ & $\mathbf{4 1 \%}$ & $\mathbf{2 4 \%}$ \\
\hline
\end{tabular}

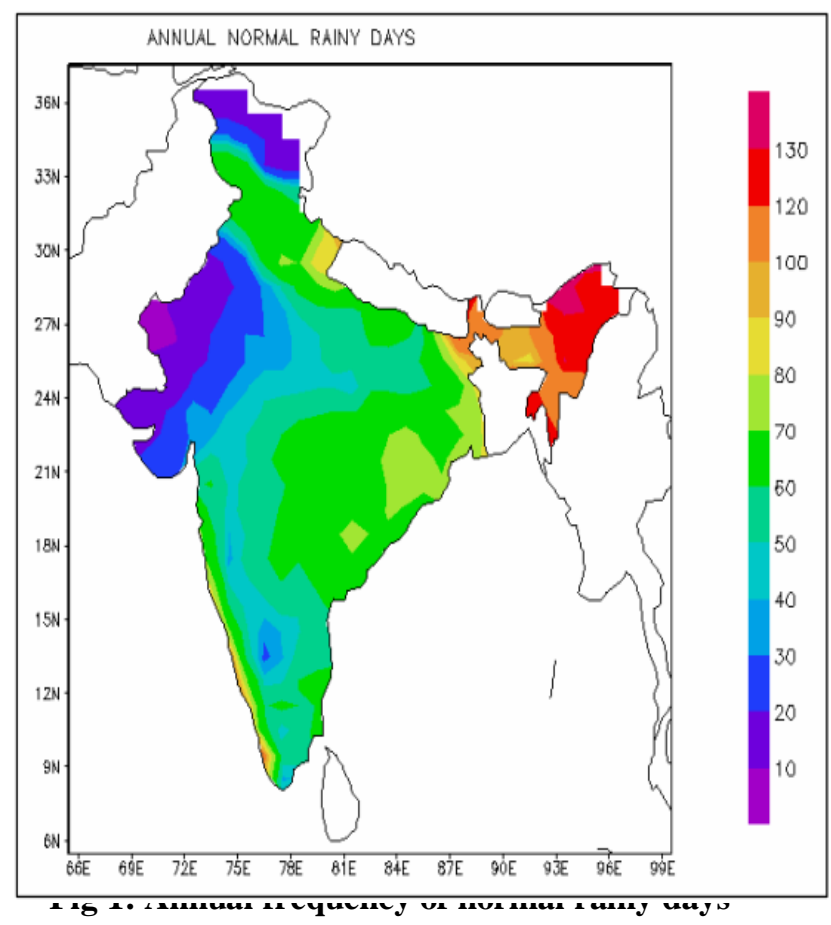

\section{STATISTICS DIAGRAM}

From the assessment of weather chance, the main weather danger effect is diagnosed. The challenge achievement is affecting via risks. these risks are mentioned using records diagram. Engineering risks and non-engineering dangers are recognized. Prediction is viable to the engineering hazard and not

he facts Diagram representing the hazard assets affecting the challenge success is shown in figure $X$. This glide chart includes diverse threat factors, in which Engineering dangers are predictable and those non-engineering risks are non-predictable. The predictable elements ought to be forecasted during the sooner degree of the challenge

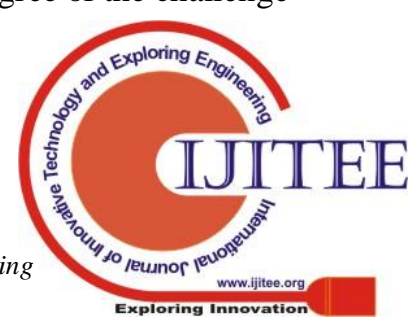


whereas the non-predictable factors contain uncertainties; this should additionally be expected for the a success of entirety of the mission due to the fact those risks will affect the value, time, great of the undertaking.

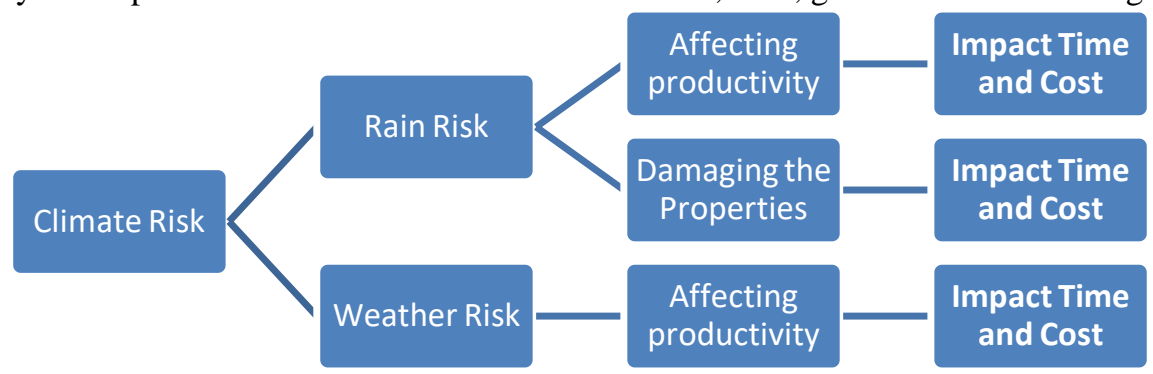

Fig 2: Climate risk flow chart

\section{CLIMATE RISK MANAGEMENT TECHNIQUES \& RESULTS}

Probability and impact (PI), Project Evaluation Review and Techniques (PERT) and Critical path method (CPM) are the market available risk management techniques. It is used widely by researcher and industrial experts. Historical data is required to asses the risk of the next project. The projected models have been shown the best output of historical simulation techniques at assessing the infrastructure projects of climate risk. Starting stage of the climate risk is call it as Predated Effective Duration (PED). Risk is vary by vary for each project. So, it is mandatory to identify the impact of each risk using simple regression model. It is a cost effective and error free tools for experts.

Effective Duration $=P D \times \sum_{n=1}^{n}\left(R D_{n}+A D_{n}\right)$

Where:

PD- Project Duration,

RD-Number of Rain Days;

AD- Productivity Affected Days

Climate Risk factor

Climate Risk Factor developed form the is predictable and unpredicted risk from the historical data. projects mainly rain days and productivity affecting

Climate Risk factor $=\frac{E D}{P D}$ Where : ED- Effective Duration; PD- Project Duration

Climate Risk Cost

Climate Risk Cost $=C R F \times I C$ Cost

Where: CRF-Climate Risk Factor; IC- Project Indirect

\section{PREDICTION CLIMATE RISK TIME AND COST}

The Historical Simulation applied various infrastructure Project and predicted Climate Risk factor effective Project duration based on the past project data demonstration in tables

Table 5: Impact of Climate risk

\begin{tabular}{|c|l|c|c|c|c|c|}
\hline $\begin{array}{c}\text { S. } \\
\text { No }\end{array}$ & \multicolumn{1}{|c|}{ Project } & Location & $\begin{array}{c}\text { Project } \\
\text { Duration } \\
\text { in days }\end{array}$ & $\begin{array}{c}\text { Predated } \\
\text { Effective } \\
\text { Duration } \\
\text { Climate Risk } \\
\text { in days }\end{array}$ & $\begin{array}{c}\text { Climate } \\
\text { Risk } \\
\text { factorin } \\
\text { duration }\end{array}$ & $\begin{array}{c}\text { Climate } \\
\text { Risk } \\
\text { Cost of } \\
\text { Project }\end{array}$ \\
\hline 1 & $\begin{array}{l}\text { Mumbai Trans } \\
\text { Harbour Link } \\
\text { (MTHL) }\end{array}$ & Mumbai & 1643 & 1328 & $19.2 \%$ & $3.45 \%$ \\
\hline 2 & Mumbai Metro line3 & Mumbai & 1643 & 1328 & $19.2 \%$ & $2.30 \%$ \\
\hline 3 & $\begin{array}{l}\text { Eastem Penipheral } \\
\text { Expressway (NE II) }\end{array}$ & Delhi & 910 & 880 & $3.3 \%$ & $0.16 \%$ \\
\hline 4 & $\begin{array}{l}\text { Bangalore Metro Rail } \\
\text { Phase-2 }\end{array}$ & Bangalore & 1640 & 1415 & $13.7 \%$ & $1.64 \%$ \\
\hline 5 & $\begin{array}{l}\text { Amaravatiiconic } \\
\text { bridge location }\end{array}$ & Vijayawada & 730 & 640 & $12.3 \%$ & $0.74 \%$ \\
\hline
\end{tabular}

Based on the above predication the west zone Project is having high impact for climate rick in mainly the Marian Project of Mumbai Trans Harbour Link Project is having high impact on the project duration is $19.2 \%$ and Cost $3.45 \%$, for the Climatic risk of monsoon season of June, July and August Raining days is high and High tide is frequently high so Marian work productivity is fully affect so the predated Effective Duration project is 1328 days, The Project Implementation Programme is developed and shuffled the resources of marine to Land area and demobilised the rental barges and own barge send to other Project so it's helped to minimised risk cost. 
Prediction of Climate Risk Management in Infrastructure Projects

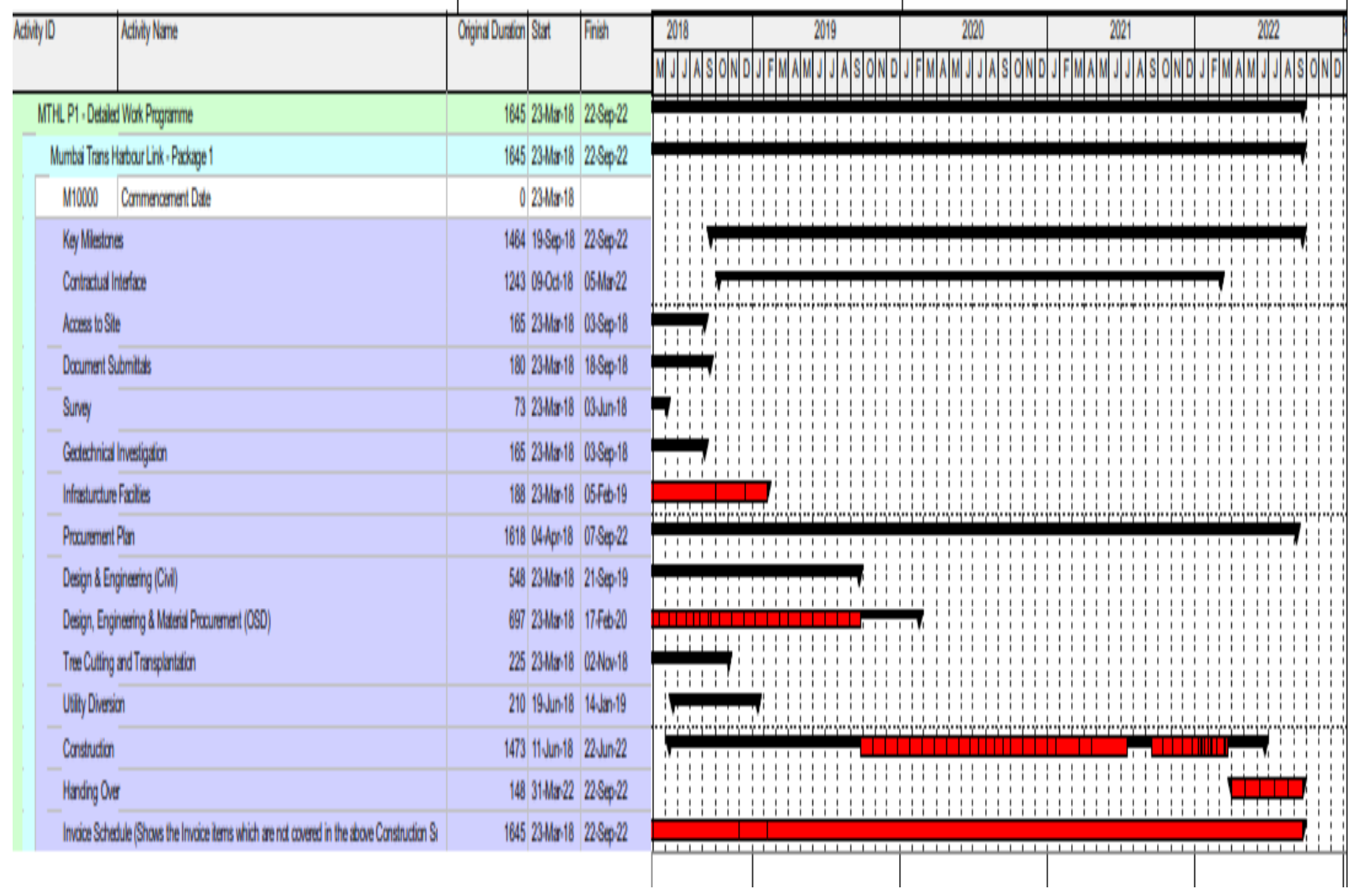

Fig 3: MTHL Project Implementation Programme

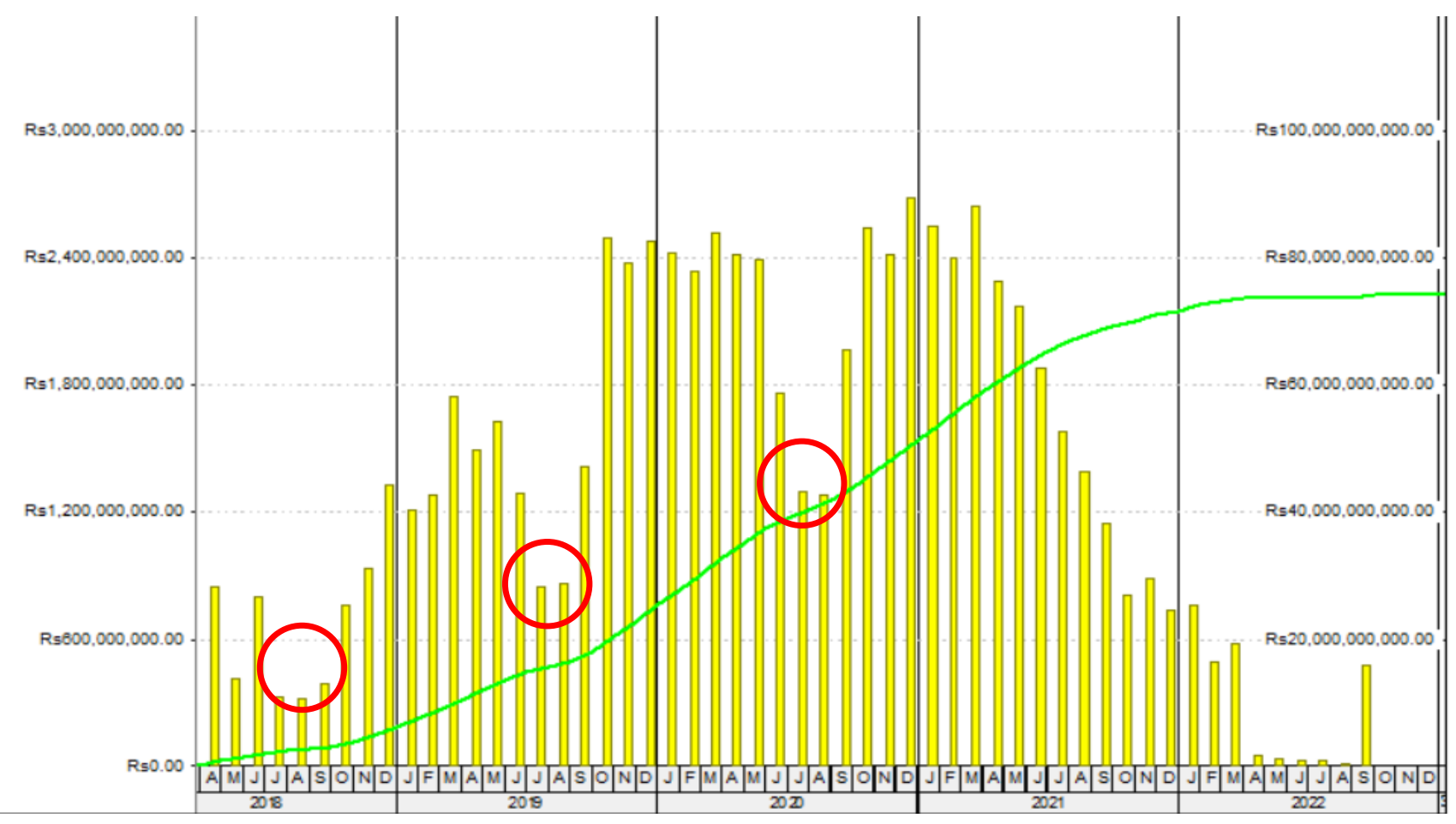

Fig 4: Expendicher cash flow

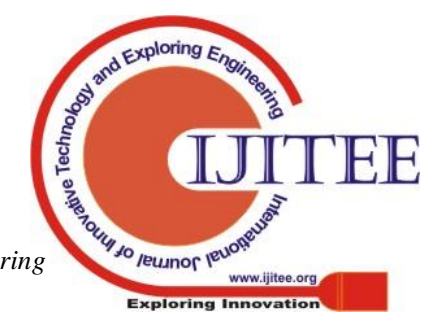




\section{CONCLUSION}

Prediction of Climate Risk Management is help for the identified the quantum of risk \& impact of time and cost of project, it's given solution to identify the rooted cost of risk make innovation method to mitigation to reduce the risk of the Project duration and Cost. The Climatic risk factors which will help to identify the effective construction duration and Climate Risk Cost of Project to complete the Project On time and Within the Budgeted cost. This study has shown that by how to predict the Climate risk based on the historical simulation and correlated with Cost and Time of Project to mitigate the complex projects of result an effective climate risk management plan can be conducted

\section{REFERENCE}

1 Richard Clough, Construction Contracting, WileyInterscience, New Mexico, 1972.

2 Journal of Civil Engineering Research 2014, 4(2A): 3136 "A Review on Critical Risk Factors in the Life Cycle of Construction Projects"

3 IOSR Journal of Mechanical and Civil Engineering (IOSRJMCE) ISSN: 2278-1684, PP: 59-65 Risk Management in Construction Industry Mr. Satish K. Kamane1, Mr. Sandip A. Mahadik2 1,2(Asst. Prof Civil Engineering Dept. Ats Sbgi Miraj)

4 International Journal of Innovative Research in Science, Engineering and Technology Vol. 4, Issue 10, October 2015 Risk Management in Construction Industry - A Case Study A. Suchith Reddy 1 Master of Science in Construction Management, Sheffield Hallam University, UK, 20101 Assistant Professor, Department of Civil Engineering, KITS College, Warangal, Telangana, India 1

5 Operational Research in Sustainable Development and Civil Engineering - meeting of EURO working group and 15th German-Lithuanian-Polish colloquium (ORSDCE 2015) Risk analysis in construction project - chosen methods. Agnieszka Dziadosza Mariusz Rejmentb a Institute of Structural Engineering, Poznan University of Technology, Piotrowo 5, 60 965 Poznan, Poland b Institute of Building Engineering, Wroclaw University of Technology, Wybrzeze Wyspianskiego 27, 50-370 Wroclaw, Poland

6 IJRET: International Journal of Research in Engineering and Technology eISSN: 2319-1163 | pISSN: 2321-7308 A STUDY OF VARIOUS FACTORS AFFECTING RISK MANAGEMENT TECHNIQUES IN CONSTRUCTION PROJECT: A CASE STUDY OF INDIA Shuaibu Saminu1, Raj Prasad2, V. Thamilarasu3 1PG Student, Department of Civil Engineering, SRM University, Chennai, India 2Assistant Professor, Department of Civil Engineering, SRM University, Chennai, India 3Professor, Department of Civil Engineering, SRM University, Chennai, India 